\title{
A Review of the Fishery and the Investigations of Roughhead Grenadier (Macrourus berglax) in Flemish Cap and Flemish Pass
}

\author{
H. Murua \\ AZTI Tecnalia, Herrera Kaia-Portualde z/g, 20110 Pasaia, Basque Country, Spain \\ F. González \\ Centro Oceanográfico de Vigo (IEO), P. O. Box 1552, 36280 Vigo, Spain \\ D. Power \\ Science Branch, DFO, P. O. Box 5667, St. John's, NL, Canada A1C 5X1
}

Murua, H., F. González, and D. Power. 2005. A review of the fishery and the investigations of Roughhead grenadier (Macrourus berglax) in Flemish Cap and Flemish Pass. J. Northw. Atl. Fish. Sci., 37: 13-27. doi:10.2960/J.v37.m567

\begin{abstract}
We review the fishery and biological investigations carried out in the Flemish Cap and Flemish Pass area during the 25 years of NAFO history. In particular, we examine the information available on the biology and population structure of roughhead grenadier recorded in the following 7 research surveys carried out in the Flemish Cap and Flemish Pass area (NAFO Div. 3LMN): Russian bottom trawl research survey (1974-86), Russian longline research survey (1982), Canadian deepwater bottom trawl research survey (1991, 1994 and 1995), European Union longline research survey (1996), European Union Flemish Cap bottom trawl research survey (1988-2004), Canadian autumn bottom trawl research survey (1978-2004) and Spanish 3NO bottom trawl research survey (1995-2004). In addition, biological data collected aboard Spanish commercial fishery vessels were analysed from 1997 to 2004. Indices of biomass from various surveys suggest stability during recent years. Most surveys indicated catch rates as well as average fish size increased with depth. Growth studies by sex demonstrated both sexes grew similarly up to 9-10 years, but the male growth was slower thereafter. Estimates of size and age at 50\% maturity and fecundity were very similar for the different data sets studied, showing a late maturity and low fecundity. All the studies examined found that the roughhead grenadier show a very wide feeding spectrum.
\end{abstract}

Key words: catches, feeding, growth, Roughhead grenadier, reproduction.

\section{Introduction}

Roughhead grenadier (Macrourus berglax Lacépède, 1802) is an abundant and widespread deepwater gadoid fish species that is distributed on both sides of the North Atlantic. In the Northwest, from New York to Davis Strait and West Greenland; and along East Greenland, Iceland, Faeroes, Norway, Spitsbergen, and the southwestern Barents Sea in the Northeast Atlantic (Leim and Scott, 1966; Savvatimsky, 1969; Geistdoerfer, 1986; Haedrich and Merret, 1988).

It is found in highest densities from 800 to $1500 \mathrm{~m}$ (Murua and De Cárdenas, 2006) although it inhabits depths between 200-2 $200 \mathrm{~m}$ (Snelgrove and Haedrich, 1985; Murua and De Cárdenas, 2006). This species is found commonly in temperatures ranging from about -0.5 to $5.4^{\circ} \mathrm{C}$ (Atkinson and Power, MS 1987).

Recent catches of grenadiers by EU-Portugal and EU-Spain in Subarea 3, previously reported to NAFO as Roundnose grenadiers (Coryphynoides rupestris Gunnerus, 1765) were in fact roughhead grenadier (Alpoim et al., MS 1994; Power and Maddock Parsons, MS 1998; Junquera, MS 1998). However, the misreporting has not yet been resolved in the NAFO official statistics. Based on these revised catch estimates more roughhead grenadier has been caught than roundnose grenadier in the NAFO area since 1990. Roughhead grenadier is caught primarily, as by-catch, in the directed Greenland halibut (Reinhardtius hippoglossoides Walbaum, 1792) bottom trawl fishery in the NAFO Regulatory Area ${ }^{1}$ (NRA) and

\footnotetext{
1 Defined by NAFO as: "the part of the NAFO Convention Area which lies beyond the areas in which Coastal States exercise fisheries jurisdiction".
} 
mainly in Div. 3LMN (Murua, 2003). The only management regulation which applies to roughhead grenadier in the NRA is a general groundfish regulation requiring the use of a minimum $130 \mathrm{~mm}$ mesh size.

With the catches of roughhead grenadier increasing continuously in the most recent years, rising to historic maximum levels, it has been recognized that reliable information is needed to properly monitor and assess the status of this "new" resource. This is even more important as the collapse of traditional groundfish fisheries and the decrease in the abundance of other fish resources of the area continue.

The biology and population structure of roughhead grenadier throughout the North Atlantic has been difficult to study due to their wide latitudinal and depth distribution. In addition the low commercial importance of roughhead grenadier has hampered research directed to this species. Nevertheless, a number of studies focused on roughhead grenadier have been carried out in Northwest Atlantic area in general, and in the Flemish Cap and Flemish Pass area in particular, since the late 1960s based on Russian, Canadian EU and Spanish research surveys. For example, information on age structure and growth rate of this species are available in the Northwest Atlantic by Savvatimsky (1989; 1994), Jorgensen (1996) and Murua (2003). An age calibration study derived from otolith reading was presented by Rodríguez-Marín et al. (2002). Depth distribution in the NAFO area was studied by Atkinson and Power (MS 1987) and also by Murua and De Cárdenas (2006). The reproductive biology in the Northwest Atlantic area was examined by Geistdoerfer (1979), Savvatimsky (1989), Murua and Motos (2000), Murua (2003) and Fossen et al., 2003. These studies have provided very valuable information with regard to roughhead grenadier population trends, depth distribution, growth, reproduction and feeding in the Northwest Atlantic.

The aim of this paper is to review the literature available regarding the fishery and biology of roughhead grenadier as well as the main research activity on roughhead grenadier in the Div. 3LMN of the NAFO Regulatory Area in order to present a comprehensive study of this marine resource. In addition, a comparison of research carried out and of survey trends from the Div. $2 \mathrm{~J}+3 \mathrm{~K}$ area to the north and west of the Flemish Pass is also considered.

\section{Material and Methods}

Data for the review were available from 8 sources which represent different research surveys carried out by Canada, Russia, Spain and EU in Div. 3LMN of the NAFO Regulatory Area (Fig. 1) in the period 1969-2004.
The Spanish commercial fishery data collected onboard of Spanish trawlers fishing in Flemish Cap and Flemish Pass were also available. The research surveys and the reference where the data was gathered, in chronological order, were the following:

i) Russian bottom trawl research surveys: Soviet Union carried out bottom trawl research surveys on the Shelf and continental slope of Labrador, around Newfoundland and West Greenland waters mainly in summer during 1967-83 down to $1300 \mathrm{~m}$. Data on distribution, abundance, length and sex composition of catches, growth, maturation, fecundity and feeding of roughhead grenadier were available for Div. 3LMN from 1969 onwards. Savvatimsky (1989) detailed the information regarding the results of these surveys.

ii) Canadian bottom trawl research surveys: The Department of Fisheries and Oceans of Canada (DFO) conducted a variety of bottom trawl research surveys with different vessels and different gears in Subareas 0 and 1 and Div. 2GHJ+3KLMNOP between $200 \mathrm{~m}$ and $1250 \mathrm{~m}$ from 1974 to 1986 . These surveys obtained data on catch distribution by depth and length and sex composition for Div. 3LMN. The results of those surveys were reported by Atkinson and Power (MS 1987).

iii) Russian longline research survey: Soviet Union conducted a longline research survey along the eastern slope of Grand Bank and Flemish Cap in 1982. Data on distribution, abundance, length and sex composition of catches, growth, age, and feeding of roughhead grenadier were available for Div. 3LMN. Data were collected during May-July and between 310 and $1000 \mathrm{~m}$ depth. The results of this survey were published by Savvatimsky (1984).

iv) Canadian deepwater research surveys: Canada conducted deepwater bottom trawl research surveys between $750 \mathrm{~m}$ and $1500 \mathrm{~m}$ in Div. 3KLM in 1991, 1994 and 1995, and part of Div. 3N in 1994 and 1995. All the surveys were conducted with the same gear. The 1991 survey was carried out in September, the 1994 in February-March and the 1995 in March-April. Data on abundance and biomass of the catch of roughhead grenadier by depth was gathered. The results of those surveys were described by Atkinson et al. (MS 1994) and Bowering et al. (MS 1995).

v) European Union longline research survey: EU-Spain and EU-Portugal carried out a longline research survey between $700 \mathrm{~m}$ and $3000 \mathrm{~m}$ in Div. 3LMN during April-May 1996. Length and sex composition 


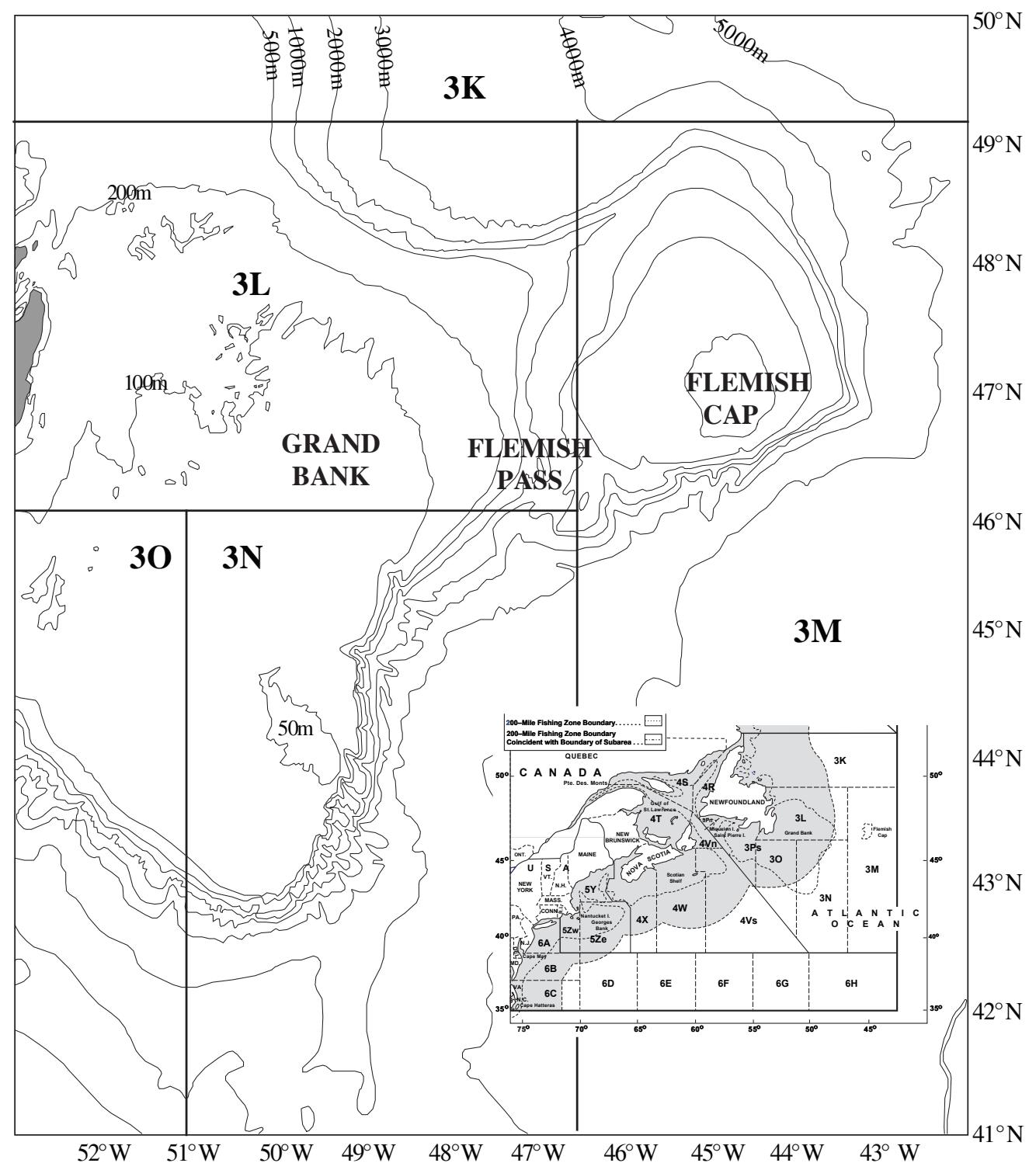

Fig. 1. Map illustrating the location of the NAFO area studied.

of the catches, yields, depth distribution of species and biological data for reproductive studies were collected in this survey. The results of this research were presented by Murua and Motos (2000) and Murua and De Cárdenas (2006).

vi) European Union Flemish Cap research surveys: Bottom trawl research surveys were carried out by EU-Spain and EU-Portugal in Div. 3M down to $720 \mathrm{~m}$ in July during 1988-2004. Data on abundance, length and sex composition of catches, biological data on growth, sex-ratio, maturity and fecundity for roughhead grenadier was available from this survey. Murua et al. (MS 2005) presented roughhead grenadier investigations of this survey and Casas and González-Troncoso (MS 2005) described the survey procedure. In 2003 the survey vessel was replaced by a new research vessel. In order to maintain the data series, comparative fishing trials were carried out in 2003 and 2004 to develop conversion factors for the species sampled and, therefore, the former series of $\mathrm{R} / \mathrm{V}$ Cornide de Saavedra was transformed to the new R/V Vizconde de Eza units (González-Troncoso and Casas, MS 2005).

vii) Canadian autumn bottom trawl research surveys: Stratified-random bottom trawl research surveys 
have been conducted in Div. 2GHJ and $3 \mathrm{KL}$ in autumn since 1978, usually in October-November. These surveys also covered Div. $3 \mathrm{NO}$ and $3 \mathrm{M}$ since 1990 and 1995, respectively (see ii) $)^{2}$. From 1995 onwards the surveys were conducted with a Campelen 1800 shrimp trawl which replaced the previously used Engel bottom trawl, however, conversion factors are not available to convert the old series into the Campelen gear units (McCallum and Walsh, 1996). Furthermore, prior to 1996 the maximum planned survey depth was generally less than $732 \mathrm{~m}$ for Div. 3LMNO and less than $1000 \mathrm{~m}$ for Div $2 \mathrm{~J}+3 \mathrm{~K}$ extending afterward in all areas to about $1465 \mathrm{~m}$. The coverage of Div. 2GH and $3 \mathrm{O}$ of this survey were incomplete and, thus, the data presented here only refer to the Div. $2 \mathrm{~J}+3 \mathrm{~K}$ and $3 \mathrm{LMN}$.

viii) EU-Spain spring bottom trawl research surveys: EU-Spain have conducted stratified-random spring bottom trawl research surveys down to $1500 \mathrm{~m}$ in the NAFO Regulatory Area of Div. 3NO since 1995. In 2001 the vessel and the trawl gear were replaced. In order to compare both series, comparative fishing trials were performed and, thus, the transformed entire series of mean catches and biomass for roughhead grenadier is available (González-Troncoso et al., MS 2005).

ix) In addition, biological data collected aboard Spanish commercial fishery vessels were analyzed from 1997 to 2004. These data, up to 2003, were presented by Murua (2003).

In all the Canadian and European Union datasets roughhead grenadier length was measured from tip of snout to base of first anal fin ray, in $0.5 \mathrm{~cm}$ intervals, as adopted by NAFO in June 1980 as a standard measurement for roundnose and roughhead grenadiers (Atkinson, 1991). Russian investigations measured the total length of roughhead grenadier, so in order to standardize and compare the results between surveys total length was converted to pre-anal fin length (AFL) using total length - pre-anal fin length relationship presented by Murua and $\operatorname{Motos}(2000)\left(L_{T}(\mathrm{~cm})=9.2499+2.196 * A F L(\mathrm{~cm}) ; R^{2}\right.$ $=0.9536 ; n=113)$.

Age estimation was determined by the readings of otoliths in the case of investigations carried out by EU, and by readings of scales in the case of Russian and Greenlandic researchers. There are several difficulties in roughhead grenadier age reading both from otoliths and scales (Sav- vatimsky, 1984); in larger fish (more than 9 years old) this is even more complicated because many rings are present and they lie close to each other. However, a calibration of age reading estimates, derived from otoliths readings, showed that an $80 \%$ agreement was reached between three different readers, the differences being \pm 1 year in otoliths between $2-10$ years and \pm 1 or 2 years in fish older than 10 years (Rodríguez-Marín et al., 2002).

\section{Results and Discussion}

\section{Catch History}

Roughhead grenadier is distributed on both sides of the North Atlantic and throughout NAFO Subareas 0 to 3 in the Northwest Atlantic waters. However, for assessment purposes NAFO Scientific Council considers the population of Subarea 2 and 3 as a single stock (NAFO, 2005). Nevertheless, the stock structure of this species in the North Atlantic remains unclear because there is little information with regard to the number of different populations that may exist and their relationship. A recent study of population genetics based upon samples collected in West Greenland, East Greenland and the Norwegian Sea suggested three different stock units with their own gene pools (Katsarou and Naevdal, 2001).

The corrected catch history from Subareas 2 and 3 after 1987 (Table 1) indicates that catches increased sharply between 1989 and 1990 then gradually until peaking at about 7200 tons in 1998. Since then catches decreased steadily to about 4000 tons in 2003. At present most catches are taken in Div. 3LMN and with only small amounts recorded from SA 2. In Div. 3L, 3M and 3N, catches showed the same pattern as in the entire distribution of the stock (Table 1).

\section{Biomass Trends of Surveys}

The main source of information with regard to trends in the abundance and biomass of roughhead grenadier in the NAFO area come from research surveys since there is no analytical assessment model used for this stock.

There are four survey series with data available from the Flemish Cap (Div. 3M) and Flemish Pass (Div. 3LMN) area, covering either depths to $720 \mathrm{~m}$ or $1500 \mathrm{~m}$ (the whole data from Div. $3 \mathrm{~L}$ and $3 \mathrm{~N}$ is presented here). Total survey biomass index of EU Flemish Cap research survey increased from its lowest level at 800 tons in 1989 to a peak of about 3000 tons in 1993 then decreased steadily to about 1200 tons in 1997. The index remained stable

\footnotetext{
2 The first years of Canadian autumn bottom trawl research survey (1978-86) are also included in the work of Atkinson and Power (MS 1987), i.e. point (ii).
} 
TABLE 1. Revised roughhead grenadier catches, updated from Power and Maddock Parsons (MS 1998), González et al. (MS 2004), Vargas et al. (MS 2004) and Vaskov et al. (MS 2004).

\begin{tabular}{|c|c|c|c|c|c|c|c|c|c|c|}
\hline \multirow[b]{2}{*}{ Year } & \multicolumn{9}{|c|}{ Roughhead Grenadier Nominal Catches (tons) by Division } & \multirow[b]{2}{*}{ TOTAL } \\
\hline & $2 \mathrm{G}$ & $2 \mathrm{H}$ & $2 \mathrm{~J}$ & $3 \mathrm{~K}$ & $3 \mathrm{~L}$ & $3 \mathrm{M}$ & $3 \mathrm{~N}$ & 30 & Other & \\
\hline 1987 & & & & & 912 & 7 & 82 & & & 1001 \\
\hline 1988 & & 1 & & & 907 & & 52 & & & 960 \\
\hline 1989 & & 2 & & 3 & 289 & 28 & 11 & & & 333 \\
\hline 1990 & & 1 & 32 & & 2211 & 688 & 312 & & & 3244 \\
\hline $1991^{\mathrm{a}}$ & & & 12 & 113 & 2543 & 497 & 1093 & 10 & & 4268 \\
\hline 1992 & & & 23 & 274 & 2582 & 2961 & 760 & 125 & & 6725 \\
\hline 1993 & & & 10 & 193 & 996 & 1428 & 1680 & 61 & 27 & 4395 \\
\hline 1994 & 1 & & 2 & 35 & 585 & 2301 & 1062 & 28 & 9 & 4023 \\
\hline 1995 & 22 & 6 & 16 & 16 & 1199 & 1625 & 1074 & 20 & 4 & 3982 \\
\hline 1996 & & & & & 1945 & 888 & 1300 & 2 & & 4135 \\
\hline 1997 & 36 & 5 & 63 & 100 & 1774 & 922 & 1797 & 43 & & 4740 \\
\hline 1998 & & & & & 2766 & 2190 & 2230 & 84 & $92^{c}$ & 7270 \\
\hline $1999^{b}$ & & & & 61 & 2037 & 3127 & 1705 & 180 & $49^{c}$ & 7160 \\
\hline $2000^{\mathrm{b}}$ & & & & 139 & 1382 & 2109 & 888 & 38 & & 4767 \\
\hline $2001^{\mathrm{b}}$ & & & & 97 & 1465 & 753 & 754 & 48 & & 3117 \\
\hline $2002^{b}$ & & & & 147 & 1905 & 869 & 700 & 36 & & 3657 \\
\hline $2003^{b}$ & 1 & 4 & 16 & 91 & $1342^{\mathrm{c}}$ & 886 & $1201^{\mathrm{c}}$ & $443^{c}$ & & $3984^{c}$ \\
\hline
\end{tabular}

to 2002, with the exception of larger increases in 1998 and 2001, and then increased substantially during last two years reaching the highest value of the time series at about 3600 tons in 2004 (Fig. 2). The pattern of biomass index of EU research survey is similar to the catch history of Div. 3M, although the highest commercial catches of roughhead grenadier were taken in 1992.

The biomass index of the Spanish 3NO spring research survey did not show a clear trend from 1997 to 2002, however, since then the biomass increased and reached the highest value in the time series at about 11400 tons in 2004 (Fig. 2).

The Canadian deep water research survey index also showed an increasing trend from 12000 tons (Div. 3LM) in 1991 to 34000 tons in 1995 (Bowering et al., MS 1995). However, the increased estimates for Div. $3 \mathrm{~L}$ and $3 \mathrm{M}$ in 1994 were due, at least in part, to the increased area covered by the survey (Atkinson et al., MS 1994).

The Canadian autumn stratified-random bottom trawl research survey indices are presented by Division $(2 \mathrm{~J}+3 \mathrm{~K}$, $3 \mathrm{~L}, 3 \mathrm{M}$, and $3 \mathrm{~N}$ ) for all strata surveyed and for strata less than $750 \mathrm{~m}$ (Fig. 3). As noted previously, the indices from 1978 to 1994 with the Engel trawl and from 1995 to 2004 with the Campelen trawl are not directly comparable and will be described separately. The total biomass index for Div. 2J and 3K with the Engel trawl suggests an almost continuous decrease from about 21500 tons in 1978 reaching the lowest at about 800 tons in 1994. Both biomass indices $(<750$ and $<1500 \mathrm{~m})$ followed very similar patterns because the depth coverage most times did not go beyond $1000 \mathrm{~m}$. The total biomass index with the Campelen trawl has continuously increased from about 7500 tons in 1996 to about 15000 tons in 2004. It is also important to note that a good portion of these estimates were derived from depths $>1000 \mathrm{~m}$ which had not been sampled sufficiently in the Engel series prior to 1995. However, the increasing trend since 1996 is less pronounced for the biomass index for depths $<750 \mathrm{~m}$ (in 2003 the coverage was incomplete). The biomass index for the period of Engel trawl for the autumn research survey in Div. 3L followed a similar decreasing pattern as Div. $2 \mathrm{~J}+3 \mathrm{~K}$ from 1985 until 1994 while in Div. 3N the surveys showed a stable pattern but with much lower survey estimates and area of occurrence than in Div. $2 \mathrm{~J}+3 \mathrm{KL}$. The Campelen indices since 1996 show no trend in Div. 3L for the total area $<1500 \mathrm{~m}$ averaging about 15000 tons but suggest an increase from 1995 to 2001 and a decline thereafter in strata $<750 \mathrm{~m}$. In Div. $3 \mathrm{~N}$ there is an indication of an increase from about 1400 tons in 1995 to 5300 tons in 
Roughhead grenadier biomass index (1988-2004)

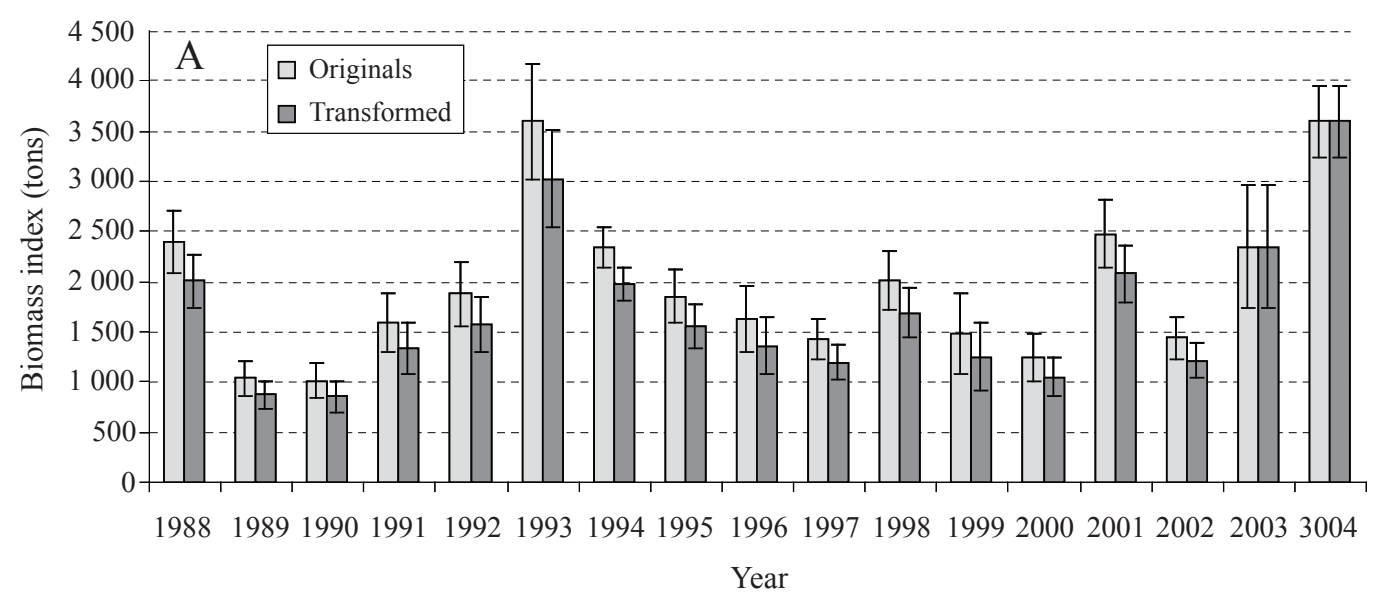

Roughhead grenadier biomass index (1997-2004)

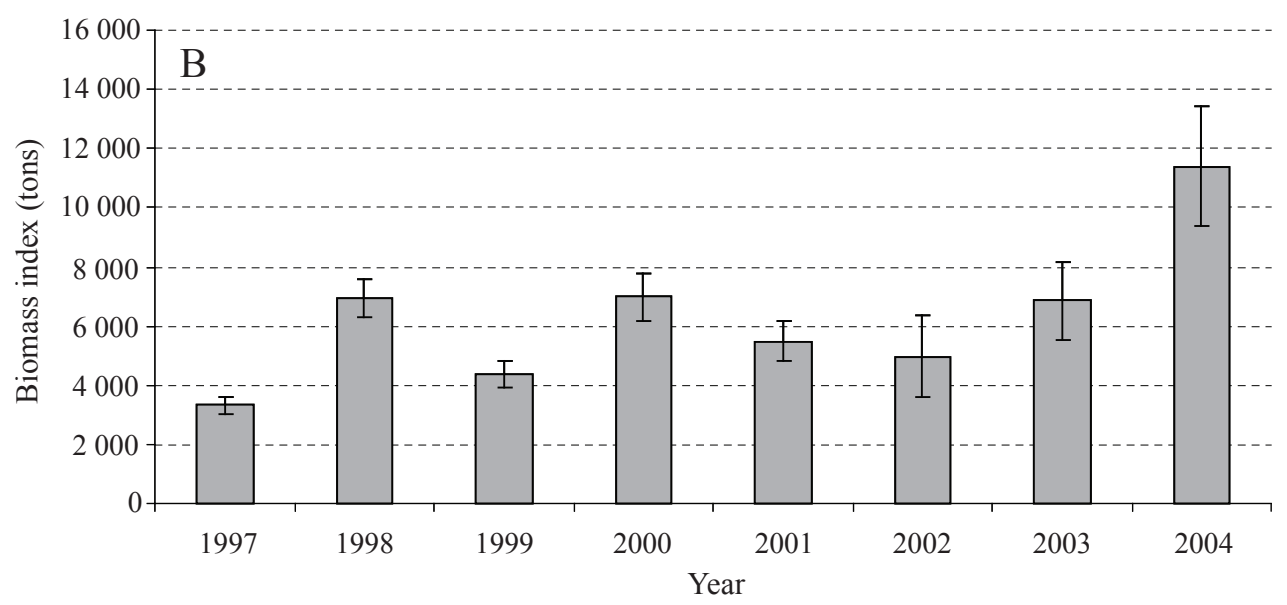

Fig. 2. Total biomass estimated by the swept area method for the area studied during (A) the EU Flemish Cap (3M) bottom trawl research survey (1988-2003, depths $<720 \mathrm{~m}$ ) and (B) the Div. 3NO Spanish bottom trawl research survey (1997-2004, depth $<1500 \mathrm{~m})$.

2004 for strata $<750 \mathrm{~m}$. The biomass for Div. 3M for the autumn research surveys showed a decreasing trend from about 6700 tons in 1997 to 4100 tons in 2000 and fluctuated between 5700 tons and 3200 tons from 2001 to 2003 . However, this only represents strata from $730 \mathrm{~m}$ to $1460 \mathrm{~m}$ on the western slopes of the Flemish Cap into the Flemish Pass area.

In summary, it can be concluded from the survey data examined here that the biomass decreased from early 1980s to 1994 and then has been increasing during recent years. In most of the surveys analyzed here the biomass index of 2004 was about the highest since the mid-1990s for each series. However, it should be mentioned that the lack of conversion factors for gears and different coverage of areas and depths for Canadian autumn research survey make it difficult to compare surveys results before and after 1995 .

\section{Catch Composition}

Among the eight research surveys analyzed there are only three with available information about the relative catch composition of roughhead grenadier in the literature. Based on weight caught using longline fishing gear, roughhead grenadier made up $65 \%$ in the Russian deepwater research survey fishing at depths to $1000 \mathrm{~m}$ and $31 \%$ in the EU deepwater research survey to $3000 \mathrm{~m}$ (57\% taking 

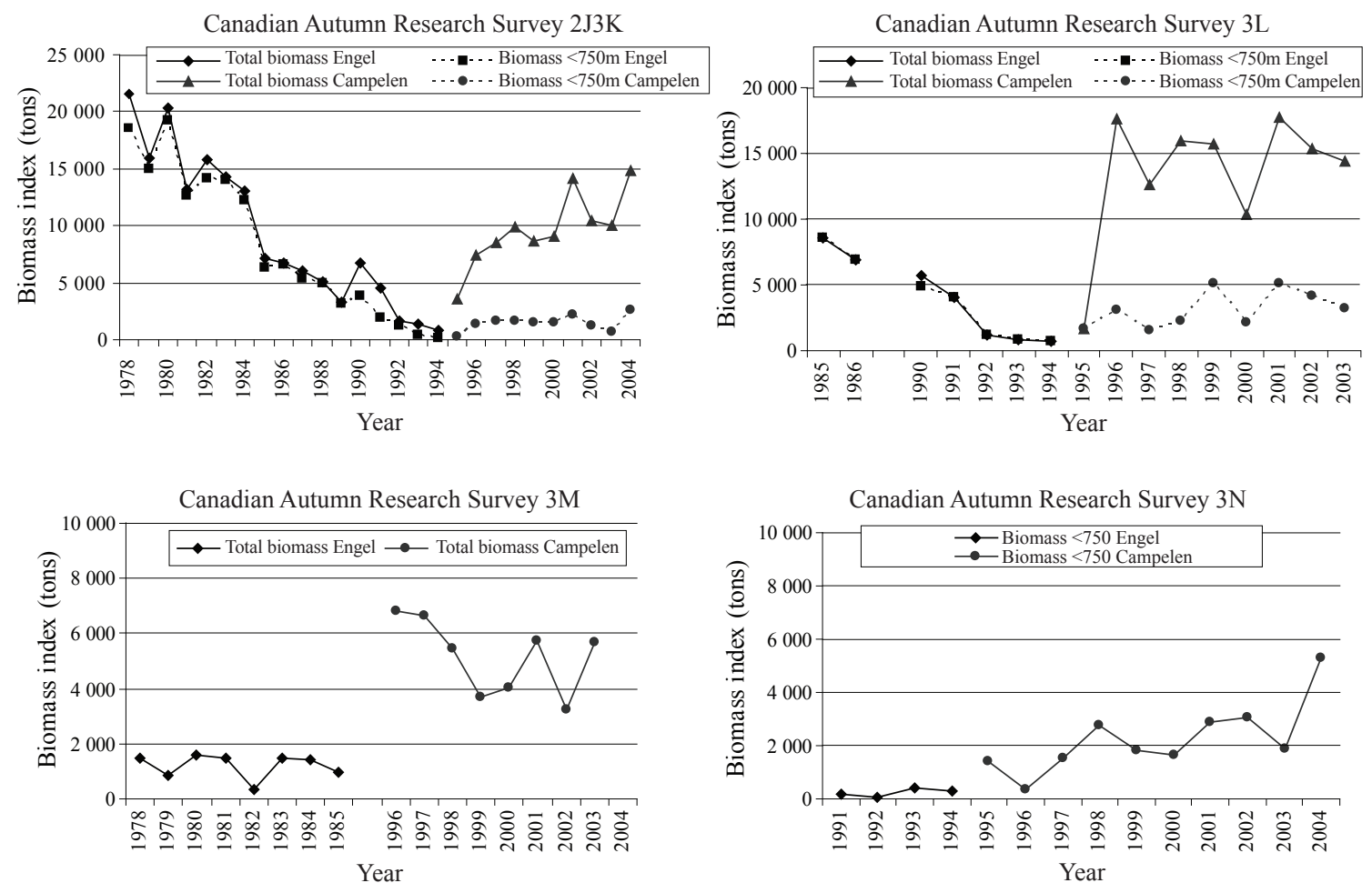

Fig. 3. Total biomass estimated by the swept area method for the different Divisions studied during the Canadian autumn bottom research trawl survey (1978-2004), both covering depth $<750 \mathrm{~m}$ and $<1500 \mathrm{~m}$.

into account depths up to $1400 \mathrm{~m}$ (De Cárdenas, pers. comm.)). The percentage of roughhead grenadier in the EU Flemish Cap bottom trawl research surveys was on average less than $5 \%$ of the total catch weight. The percentage of roughhead grenadier based on information from the Spanish commercial fishery using bottom trawls, fishing up to $1400 \mathrm{~m}$, was $15 \%$ for Div. $3 \mathrm{LMN}$ and $25 \%$ for Div. 3M, respectively, in 2003 (González et al., MS 2004). In any case, it seems that the longline is more selective catching roughhead grenadiers than the bottom trawl. The difference in the roughhead grenadier selectivity between trawl and longline was also reported by Jørgensen and Boje (MS 1992) and Jørgensen (1995).

\section{Depth Distribution}

The minimum and maximum depth covered varied among the surveys considered. All the research surveys found that there were no significant catches of roughhead grenadiers in depths of less than $200 \mathrm{~m}$ (Atkinson and Power, MS 1987; Savvatimsky, 1984; 1989; Murua and González, MS 2004; Murua and De Cárdenas, 2006). The EU longline research survey, which surveyed areas in Div. 3LMN down to $3000 \mathrm{~m}$, showed that the bathymetric limit of roughhead grenadier is around $2000 \mathrm{~m}$ (Murua and De Cárdenas, 2006) (Fig. 4).

\section{Mean Catch and Mean Length/Weight by Depth}

Most of the research surveys (Atkinson and Power, MS 1987; Savvatimsky, 1984; 1989; Bowering et al., MS 1995; Murua, 2003) indicated that the catch rates increased with depth. The best catch rate for the Canadian trawl research survey (Atkinson and Power, MS 1987) and the EU Flemish Cap research survey (Murua, 2003) were found at the deepest strata of each survey $(700-800 \mathrm{~m})$. The EU deepwater longline research survey (Murua and De Cárdenas, 2006) and the Russian trawl research survey (Savvatimsky, 1989) showed that the best catch rates were taken at depths between 1000 and $1200 \mathrm{~m}$ and they decreased in depths greater than around $1200 \mathrm{~m}$ (Fig. 5). The Russian deepwater research survey (Savvatimsky, 1984) showed a contradictory picture, with the catch rates being highest at depths between 400 and $500 \mathrm{~m}$ then decreasing at greater depths. However, the latter survey conducted with longline gear only occupied 20 stations with only three of them being beyond $700 \mathrm{~m}$ (Savvatimsky, 1984). Given the results of the research surveys with their varying depth ranges and timing of the surveys it could be concluded that generally the best catch rates of this species are taken around $1000 \mathrm{~m}$.

The mean length or weight of roughhead grenadier in most of the research surveys analysed here increased 


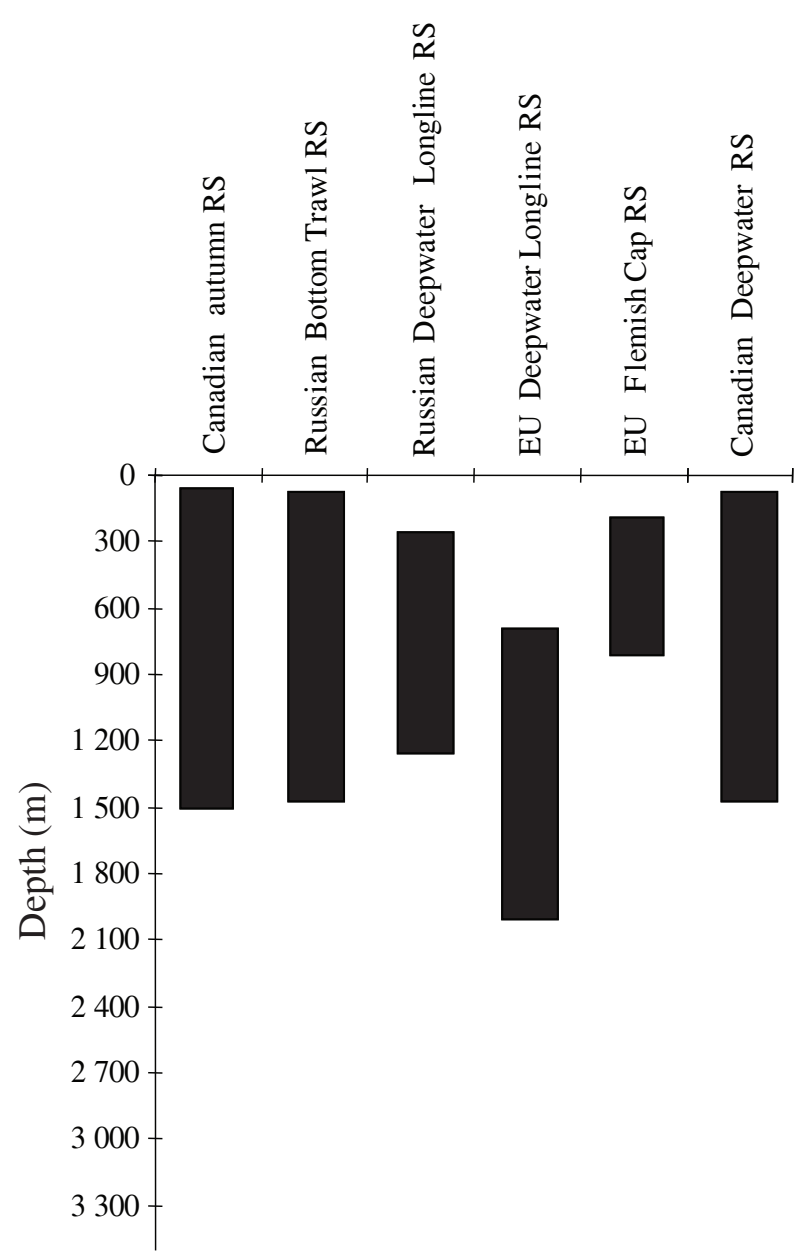

Fig. 4. Depth distribution of roughhead grenadier caught in different surveys in NAFO Div. 3LMN. Data from Atkinson and Power (MS 1987), Murua and De Cárdenas (2006), Savvatimsky (1984), Savvatimsky (1989), and Murua and González (MS 2004).

continuously with depth with the exception of the Russian bottom trawl research survey where both the mean length for males and females decreased as the depth increased up to $600 \mathrm{~m}$ in Div. 3N (Savvatimsky, 1989) (Fig. 5). Atkinson and Power (MS 1987) found that in general a clear trend did not exist between mean weight and depth; although they found larger fish in some of the shallowest stations, particularly in Div. 3LN. The appearance of larger fish in the shallowest waters surveyed was also found by Parsons (MS 1976), especially in Div. 3N. However, both these studies only sampled depths to about $700 \mathrm{~m}$ in Div. 3LMNO where the increasing trend starts to be more evident from other studies (Murua and De Cárdenas, 2006). Investigations in east Greenland also found that the mean length increased with depth (Fossen et al., 2003). Overall, despite some contradictory trends with regard to change in length by depth, which may be affected by seasonal differences, it seems that an increasing trend of mean length with depth is the norm.

The mean length of the catch in all research surveys was smaller for males than for females. Savvatimsky (1984) gave an average AFL of $18.5 \mathrm{~cm}(49.8 \mathrm{~cm}$ total length) and $24.5 \mathrm{~cm}(63 \mathrm{~cm}$ total length) for males and females respectively in Div. 3LMN based on a longline research survey in 1982. Savvatimsky (1989) also found an average AFL of 18.0 (47 cm in total length) and 21.2 $(54.6 \mathrm{~cm})$ for males and females, respectively, in Div. 3KL and $3 \mathrm{~N}$ for bottom trawl research surveys from 1967-83. In the EU Flemish Cap research survey, the average mean pre-anal fin length of males and females was 15.4 and $17.0 \mathrm{~cm}$, respectively, for the period 1991-2003 (Murua, 2003). Murua and De Cárdenas (2006) gave a mean length for both sexes of $20.6 \mathrm{~cm}$ with females making up $71 \%$ of the catch for the EU deepwater longline research survey. These differences are likely related to the fishing gear selectivity (longline $v$ s trawl) and depth where fish were caught, because as noted previously length has a tendency to increase with depth, from the shallowest stratum to the deepest (Murua and De Cárdenas, 2006).

\section{Age and Growth}

Age of roughhead grenadier has been estimated by two methods: scales (Savvatimsky, 1989, 1994; Jorgensen, 1996) and otoliths (Murua, 2003). Using scales Savvatimsky $(1989 ; 1994)$ found that samples from Div. 0B, $2 \mathrm{GHJ}$ and $3 \mathrm{~K}$ in the $48-50$ total length range (17.5-18.5 pre-anal fin length) were between 8 and 11 years. The age reading derived also from scales of fish of AFL ranging from 17.5-18.5 sampled in NAFO Div. 1ABCD were about 9-10 years (Jorgensen, 1996). Based on otolith samples from Flemish Cap and Flemish Pass areas, Murua (2003) found that fish between 17.5 and $18.5 \mathrm{~cm}$ pre-anal fin length were between 9-10 years old (combined for male and female). Similarly, based on otolith samples from commercial fleet, the oldest male and female were estimated to be about 20 and 28 years old respectively ( 24 and $47 \mathrm{~cm}$ pre-anal fin length for males and females). Savvatimsky $(1989 ; 1994)$ similarly found that the oldest male and female were 13 and 22 years old, respectively. Jorgensen 1996 also found that females (19 years) live longer than males (13 years); which is in agreement for other species of grenadiers (Bergstad, 1990; Merrett and Haedrich, 1997). Therefore, roughhead grenadier is considered to be long lived and slow growing species (Hureau et al., 1979; Murua, 2003).

Murua (2003) found that the mean length at age based on otoliths was similar for males and females for individuals younger than 9-10 years old, but males grow 
A Canadian autumn bottom trawl RS

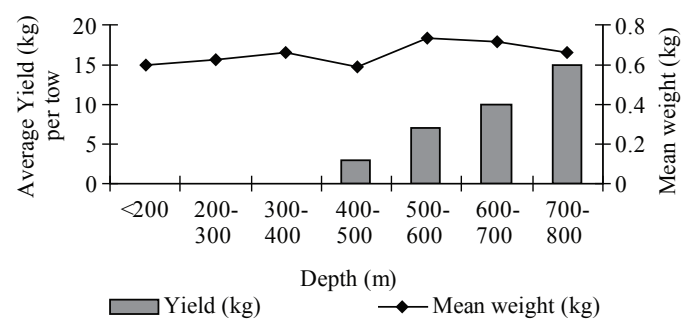

C Russian deepwater longline RS

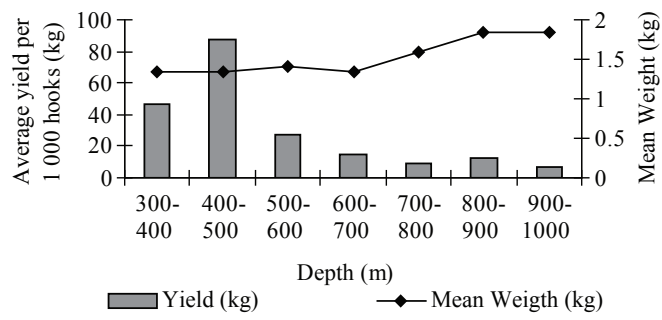

B EU deepwater longline RS

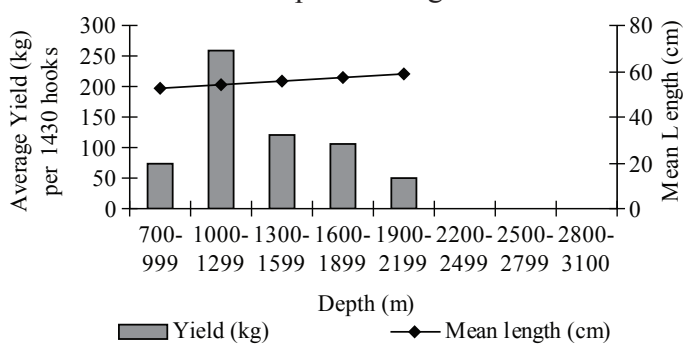

D Russian bottom trawl RS

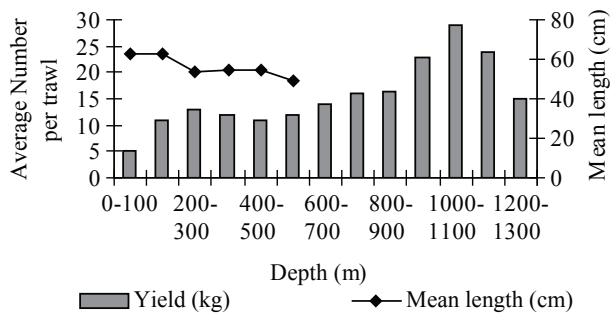

E EU Flemish Cap bottom trawl RS

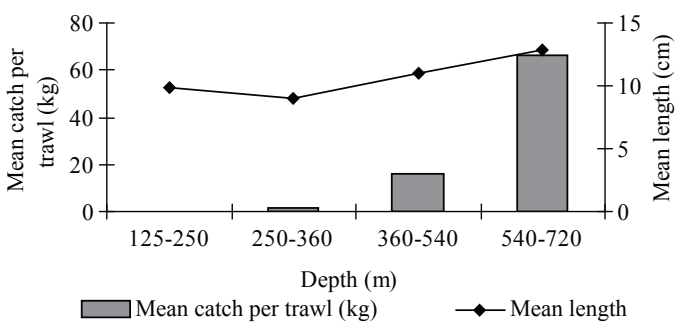

Fig. 5. Evolution of average yield $(\mathrm{kg})$ and mean length of roughhead grenadier by depth for the different surveys: (A) Canadian bottom trawl research survey (Atkinson and Power, MS 1987), (B) EU Deepwater longline research survey (Murua and De Cárdenas, 2006), (C) Russian Deepwater longline research survey (Savvatimsky, 1984), (D) Russian bottom trawl research survey (Savvatimsky, 1989), and (E) EU Flemish Cap bottom trawl research survey (Murua and González, MS 2004).

slowly from this age onwards and did not grow as large as females. This study also found that female growth rate decreased at 20 years old (at about $35 \mathrm{~cm}$ on AFL). Savvatimsky (1984) also found similar growth pattern using scales, with differences between sexes starting at around 10 years (Fig. 6). Both studies concluded that the growth trajectories of males and females are different from 9-10 years old, which would have great implications for the assessment of potential yield of this fish resource.

The relationships between fish length and weight available in the literature were assumed to be adequately described by the multiplicative function (expressed as Weight $=a$ Length $^{b}$ ). Murua (2003) published the relationship for males and females separately and found that females were heavier than males at length. Savvatimsky (1989; 1994) and De Cárdenas et al. (MS 1996) provided length-weight relationships for sexes combined from
Div. 0B, 2GHJ, 3KLMNO and Div. 3LMN, respectively. When comparing the combined length-weight relationship between surveys, we found that Russian bottom trawl and longline research surveys (Savvatimsky 1989; 1994) presented very similar length-weight relationship whereas the EU deep longline research survey showed the heavier fish for a given length (De Cárdenas et al., MS 1996). In contrast to those relationships, the EU Flemish Cap bottom trawl research survey showed fish with less weight for the same length (Fig. 7). In other words, the coefficient of allometry ( $b$ parameter of length-weight relationship) was higher in the EU deep longline research survey and was lowest in the EU Flemish Cap bottom trawl research survey. However, theses differences were small and this variability could be explained by the depth range covered by different surveys as well as by the different length range sampled in different surveys, i.e. the number of larger fishes were larger in the deepest surveys. 

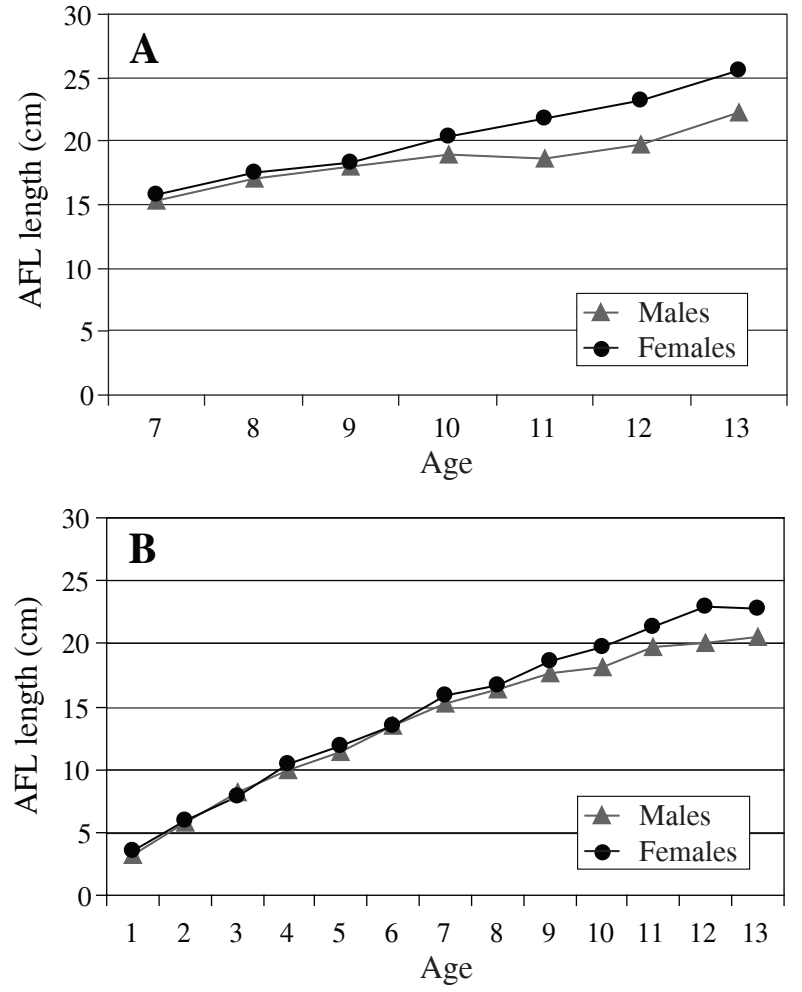

Fig. 6. Roughhead grenadier mean pre-anal fin length by age for both surveys analysed: (A) Russian bottom trawl research survey (Savvatimsky, 1989) and (B) EU Flemish Cap research survey (Murua and González, MS 2004).

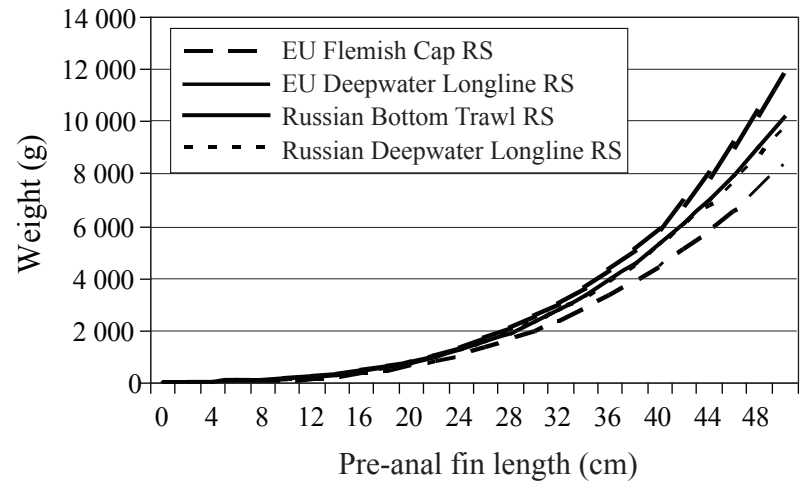

Fig. 7. Roughhead grenadier pre-anal fin length-weight relationship for different surveys: EU Deepwater research survey (Murua and De Cárdenas, 2006), Russian Deepwater longline research survey (Savvatimsky, 1984), Russian bottom trawl research survey (Savvatimsky, 1989), and EU Flemish Cap research survey (Murua and González, MS 2004).

\section{Sex Ratio}

Females made up $51 \%$ of the catches during the EU Flemish Cap bottom trawl research survey. This is lower than that reported by Savvatimsky (1989) for the Russian bottom trawl research surveys and Atkinson and Power (MS 1987) for Canadian bottom trawl research surveys where females made up $62.5 \%$ and $60 \%$ of the catch, respectively. On the other hand, Murua and De Cárdenas (2006) and Savvatimsky (1984) found that the sex ratio for longline research surveys were higher than for trawl surveys, where females made up $71.4 \%$ and $95.4 \%$ of the catch, respectively. The differences in the overall sex ratio found could be related to a number of factors. For example, different depth range covered by research surveys (longline surveys were deeper), or differences in selectivity between bottom trawl and longline gears (Jorgensen and Boje, MS 1992; Jørgensen, 1995) or difference in timing of the surveys. However, these results would not be unexpected given that mean length in most of the surveys increased with depth (Fig. 5) and the proportion of females in large length-classes is higher (Fossen et al., 2003; Murua, 2003) because males do not grow as large as females.

The length distribution by sexes found in all research surveys showed that proportion of males diminished in the larger fish (from $20 \mathrm{~cm}$ pre-anal fin length) and there
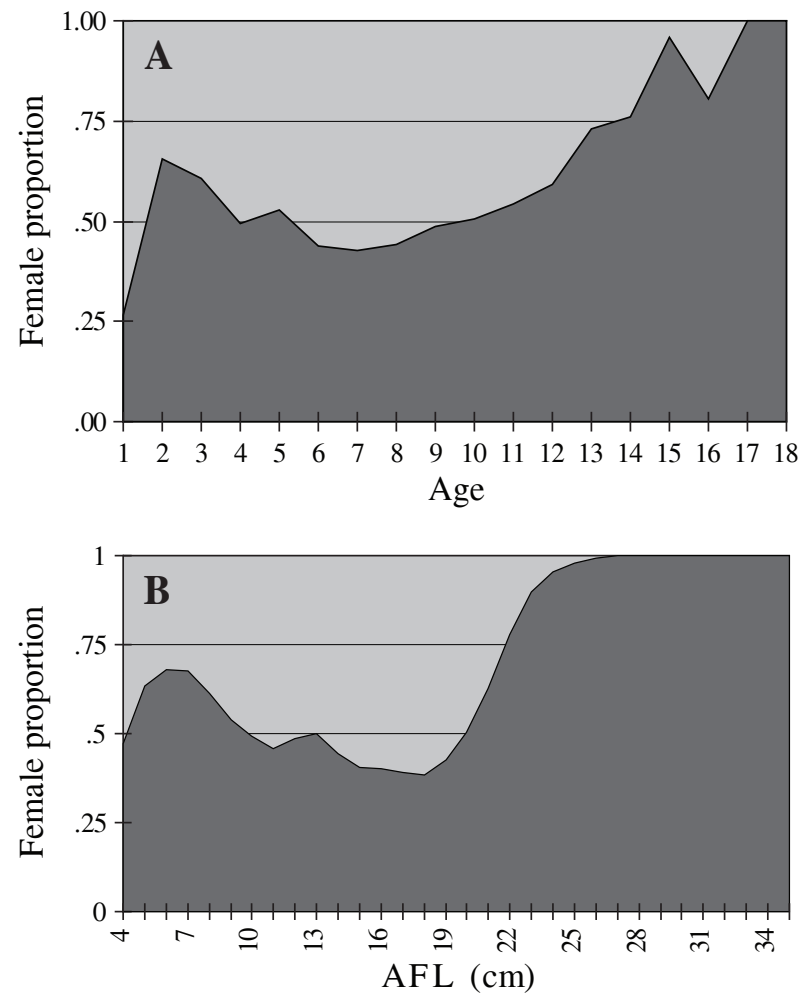

Fig. 8. Female sex-ratio in the Flemish Cap research survey by (A) age and (B) length for the period 1988-2003 from Murua and González (MS 2004). 
were no males in largest length-classes. Results for the EU Flemish Cap research survey (Fig. 8) showed the female proportion fluctuated around $40-50 \%$ during the first 10-12 years (up to $20 \mathrm{~cm}$ in AFL). It increased from age 12 (AFL $20 \mathrm{~cm}$ ) upwards and females were $100 \%$ of the catches in large length-classes. Both Russian research surveys (Savvatimsky 1984; 1989 and 1994) found similar sex-ratios for Northwestern Atlantic to that of EU Flemish Cap, i.e. males were more abundant in the middle of the length range.

Indirect evidence of increasing trend of mean length by depth and skewed female ratio in larger length-classes gathered in all the studies suggested that female sex ratio would increase with depth; which is the case for some other groundfish species in general (Bergstad, 1990) and grenadiers in particular (D'Onghia et al., 2000). In fact, in the EU Flemish Cap research survey the female proportion was $40 \%$ in depths less than $350 \mathrm{~m}$, increased to $50 \%$ in depths $<500 \mathrm{~m}$ and reached $60 \%$ in depths between 500 and $700 \mathrm{~m}$. Savvatimsky (MS 1983) found that almost all fish caught beyond $700 \mathrm{~m}$ in Div. 3LMNO were females, which was confirmed by the EU deepwater research survey where the female ratio was around $80 \%$ from $700 \mathrm{~m}$ onwards. Atkinson and Power (MS 1987) suggested an increasing trend of female proportion by depth in Div. 3LMNO while they did not find such a trend in northern Divisions. The latter authors also cited that Geistdoerfer (1979) indicated no clear trend of female ratio by depth. Geistdoerfer (1979) and Atkinson and Power (MS 1987) also pointed out that the sex ratio might vary with latitude or Division, suggesting that the female proportion was higher in lower latitudes. Other authors suggested (Geistdoerfer, 1979; Magnusson, MS 1978) that the sex-ratio might vary with season which would in turn complicate the outcome of these analyses. Moreover, Fossen et al. (2003) found that in the east Greenland area the percentage of males was around $80 \%$ in all depths sampled with a bottom trawl whereas the percentage of males increased from $60 \%$ to $80 \%$ in deeper strata $(1400-1600 \mathrm{~m})$ sampled with the longline. They suggested that the reason for the catches being mainly dominated by males might be differences in selectivity by sexes or because the sample was not representative.

Although the results with regard to sex-ratio by depth are somewhat conflicting, based on the best available data reviewed here, it could be concluded that the female ratio increased with depth. This conclusion is drawn mainly using the EU Flemish Cap bottom trawl research surveys which covered the same study area in a standardized way since 1988, whereas the results of other studies are based on single years with different coverage of depth-strata between years and areas. On the other hand, if there is an increasing trend of female ratio with latitude and if the selectivity is different by sexes, at least for longline, these would be of great importance when planning future surveys in order to monitor status of this resource and would also be an important factor in the management of this resource.

\section{Reproduction (Maturity and Fecundity)}

Only a few studies on maturity and fecundity of roughhead grenadier have been carried out in the NAFO area of Flemish Cap and Flemish Pass. Murua and Motos (2000) suggested that for roughhead grenadier in Div. 3LMN pre-anal fin length at first maturity for females was 26.2 (at 13-14 years of age). Further work carried out by Murua (2003) in the same area proposed that the sexual maturity for females began at an AFL of $28.5 \mathrm{~cm}$ and at age of 15-16 years. Recently, Fossen et al., (2003) found that pre-anal fin length at first maturity for roughhead grenadier in waters of east Greenland was $16 \mathrm{~cm}$ and $29.5 \mathrm{~cm}$ for males and females, respectively. For the north-east Atlantic, Eliassen and Falk-Petersen (1985) gave a length and age at first maturity of $28.5 \mathrm{~cm}$ and 15 years, respectively. All the values of pre-anal fin length at first maturity are very similar. However, the differences in age at maturity between Murua and Motos (2000) and other studies could be explained by the fact that they derived the age at first maturity indirectly from an age/length key constructed with samples collected in Flemish Cap research survey, which covered only the younger part of the population ( $<20$ years), i.e. the ages for similar lengths are shifted to younger ages.

As for the case of maturation studies, there are also only a few studies reporting estimates of fecundity. Savvatimsky (1989) estimated that fecundity of roughhead grenadier in NAFO Subareas 2 and 3 varied between 23100 and 54000 eggs per female $(n=4)$. Murua and Motos (2000) found that fecundity was in the range of 14400 and 80000 eggs in Div. 3LMN $(n=16)$ and Murua (2003) obtained values of fecundity ranging from 8500 to 62000 eggs $(n=17)$. With regard to other areas of North Atlantic, Eliassen and Falk-Petersen (1985) found that fecundity was in the range between 2000 and 71000 eggs $(n=24)$ and Fossen et al. (2003) estimated that fecundity vary between 17000 and 56000 eggs $(n=$ 25 ) for roughhead grenadier caught off Northern Norway and East Greenland, respectively. Although the sample size used in all the studies was unsatisfactory to estimate fecundity with any confidence all the results seem to be in accordance suggesting that roughhead grenadier has much lower fecundity than other gadoids.

With regard to the spawning season, Savvatimsky (1984; 1989) and Murua and Motos (2000) hypothesized 
that spawning period is in winter-spring in the NAFO Area, whereas Murua (2003) considered that it is no clear seasonality in the spawning in the NAFO area. On the other hand, Geistdoerfer (1979) considered that spawning takes place between late spring to early summer in Div. 2J and 3KL. Other studies in the Northeast Atlantic reported that spawning occurs between winter and spring (Yanulov, 1962; Magnusson, MS 1978; Eliassen and Falk-Petersen, 1985); although interminent spawning might be found in the rest of the year.

In general, it can be concluded from past studies that roughhead grenadier shows late onset of maturity and low fecundity. However, more extensive studies seem to be needed to correctly resolve the question of spawning timing and seasonality in the reproductive cycle of roughhead grenadier; this in turn would help to draw more definitive conclusions with regard to fecundity and maturity of this species.

\section{Feeding}

Roughhead grenadier feeds mainly on benthic organisms and it is characterized by having a wide range of prey (Hureau et al., 1979; Roman et al., 2006). There are some studies with regard to the feeding patterns and strategies of Macrouridae fishes in general, and of roughhead grenadier in particular (Marshall, 1965; Geistdoerfer, 1975) across the North Atlantic; however, our focus will be on studies carried out in the NAFO area.

Houston (MS 1983) commented that roughhead grenadier diet was composed mainly of benthic animals (91.6\%) on the Grand Banks. Podrazhanskaya (1972) and Konstatinov (1976) found that shrimps, ophiuras, and squid were the main components of the roughhead grenadier diet from Davis Strait and Northern Labrador. Geistdoerfer (1979) indicated that roughhead grenadier fed mainly on gammarids, ophiuras, polychaetes, shrimps and fishes. He also found that the importance of shrimp and fish in the diet increases with fish size. Savvatimsky (1984) concluded that the roughhead grenadier diet in Div. 3LMN consisted of a very diverse range of benthic organisms and fish. His study revealed bivalve molluscs (13.4\%), shrimp (12.4\%), fish (11.1\%) and starfishes $(10.5 \%)$ were the major components for all size groups except small roughhead grenadiers (fishes smaller than $18.5 \mathrm{~cm}$ in AFL), which did not contain fish portions. However, these results should be treated with caution because of very low indices of stomach fullness, as most of the stomachs sampled from the longline research survey were empty. In further work, Savvatimsky (1989) confirmed the results of past studies with regard to a wide diversity comprising the diet of roughhead grenadier and concluded that the favourite prey were benthic organisms, such as ophiuras $(26 \%)$, polychaetes $(19 \%)$, gastropods and bivalves $(12 \%)$, followed by different crustaceans. $\mathrm{He}$ also found that the incidence of fish and shrimp increased with grenadier length, similar to the results of Geitsdoerfer (1979). In that sense, Savvatimsky (1989) found that the abundance of small pelagic crustaceans (copepods, amphipods, euphausiids, cumacea) was high in the stomachs of small grenadiers (9.5 cm in AFL), while the main component of the food of grenadier larger than $9.5 \mathrm{~cm}$ in AFL were pandalids, pagurids, molluscs and fishes (Fig. 9 in Savvatimsky, 1989). According to Savvatimsky (1989) the total frequency of occurrence of Northern shrimp (Pandalus borealis Kroyer, 1838) in both sexes was $8.9 \%$; increasing from $3.3 \%$ in the $10-14 \mathrm{~cm}$ AFL range to $21.9 \%$ and $33.3 \%$ in the $28-32$ and $32-37$ cm AFL length-range, respectively.

Recent work by Roman et al. (2006) based upon samples collected in the EU Flemish Cap research survey in 2001-2003 confirmed the above mentioned results and concluded that roughhead grenadier showed a high diversity of prey, with the Northern shrimp being the most common prey (24\%) followed by Scyphozoa $(16.5 \%)$ and Lampadena speculigera (8.6\%), respectively. They also found that as length increased the importance of fishes in roughhead grenadier diet was more important. However, contrary to the findings of Savvatimsky $(1984 ; 1989)$ they found that roughhead mainly fed on shrimp and that the percentage of shrimp in the diet diminished with length of roughhead grenadier. They showed that the percentage of shrimp in the diet diminished from around $65 \%$ in fishes $<10 \mathrm{~cm}$ AFL, to $45 \%$ in fishes in the 10-20 AFL length range and further lessened to around $15 \%$ in the length range of 20-30. The change in the relative importance of Northern shrimp in the roughhead diet could be related to the rapid increase in shrimp biomass observed in Northwest Atlantic area in general but more particularly on the Flemish Cap since the early 1990s (Lilly et al., 2000; Koeller, 2000; Anderson, 2000).

\section{Stock Assessment}

During last assessment carried out for this stock, which is currently taken to be NAFO Subarea 2 and 3, the NAFO Scientific Council concluded that "no analytical assessment was possible with current data" (NAFO, 2005). This was partly because the information presented with regard to catch statistics was not reliable and the research survey data were incomplete to carry out such an analysis. For example, some surveys were only sporadic (Canadian deepwater research survey and Russian longline research survey), others presented a long data series but with different year to year coverage and were not useful for current 
state of the stock (Russian bottom trawl research survey, 1967-83), while the EU Flemish Cap research survey only covers the shallowest distribution $(<750 \mathrm{~m})$ of the species. Although the Canadian autumn research survey (1978-2004) covers the main latitudinal and bathymetric distribution of this species from 1996 onwards, it changed the survey gear in 1995 and the lack of a conversion factor makes it impossible to compare both series. Thus, NAFO Scientific Council considered that, in spite of the limitations, the Canadian autumn bottom trawl research survey and the Spanish 3NO research survey from 1996 provide the best survey information to monitor trends in this resource because they cover the main latitudinal and bathymetric distribution of this stock. While a historic perspective is not possible, the biomass estimates of these research surveys indicated a general increasing trend from 1996 onwards. In addition, the NAFO Scientific Council concluded that the fishing mortality proxy (catch divided by biomass of Canadian autumn research survey) was the lowest since 1995 and that EU Flemish Cap research survey and the Spanish 3NO research survey showed a good recruiting 2001 year-class. On the other hand, the commercial catch rates are not useful since the roughhead grenadier is taken as by-catch in the Greenland halibut fishery and because there is evidence that the reported catches are not truly reliable.

\section{Conclusion}

The studies summarized in this contribution were focused mainly on the NAFO areas of Div. 3LMN but also comparisons to other areas of North Atlantic suggest many common attributes with respect to life history characteristics. It could be concluded that roughhead grenadier has a prolonged life cycle, multi-aged population structure with differences in growth between males and females, late onset of maturity and low fecundity. In general, the catch rates observed in all research surveys were highest at depths around 1 000-1 $200 \mathrm{~m}$ and the mean length, as well as mean weight, increased with depth. We have also observed a skewed sex-ratio and a wide feeding spectrum that is related to fish size which in turn increases with depth. The complex multi-mode length structure and slow growth are characteristic of deepwater fishes, including grenadiers (Hureau et al., 1979; Casas, MS 1994; Savvatimsky, 1994).

The importance of gathering reliable information about biological characteristics and fisheries of this species is even more essential as the catches of this unregulated deep-water species have been increasing during recent years. Proper monitoring and assessment of the status of this "new" resource is even more important as traditional groundfish fisheries are collapsed or in poor condition. In general, the information available on the biology of this deepwater species is more extensive than what one would expect for such species. However, it is evident that there is a need of gathering accurate catch statistics in a standardized way which, and, in conjunction with a continuation of research surveys conducted in the area, would facilitate a proper assessment of this resource in the near future. Given that roughhead grenadier are a relatively long-lived species with low fecundity, they likely would not have a high productivity. This, coupled with the fact that current by-catches beyond $1000 \mathrm{~m}$ are comprised mainly of immature fish, would suggest that a prudent approach should be adopted in managing this species.

\section{Acknowledgements}

The authors are indebted to all the people who at different stages helped us to carry out the review. We also wish to thank all the personal of AZTI, IEO and DFO who have collaborated in the biological sampling and in the analysis of the samples.We specially thank Joanne Morgan for her helpful comments, suggestions and revision for improvement of this manuscript as well as the two anonymous reviewers. Special thanks are extended to Tissa Amaratunga for his valuable comments and invaluable help during last years. The study has been carried out with financial support from the European Commission (Study Contract no. XIV 96/030, XIV 98/048 and XIV 00/028), from the Department of Agriculture and Fisheries of Basque Country Government, from Spanish Institute of Oceanography (IEO) and from DFO.

\section{References}

ALPOIM, R., A. M. AVILA DE MELO, M. L. GODINHO, and E. SANTOS. MS 1994. Portuguese Research Report for 1993. NAFO SCS Doc., No. 13, Serial No. N2397, 49 p.

ANDERSON, P. J. 2000. Pandalid shrimp as indicators of ecosystem regime shift. J. Northw. Atl. Fish. Sci., 27: 1-10.

ATKINSON, D. B. 1991. Relationships between pre-anal fin length and total length of roughhead grenadier (Macrourus berglax Lacépède) in the Northwest Atlantic. J. Northw. Atl. Fish. Sci., 11: 7-9.

ATKINSON, D. B., and D. POWER. MS 1987. Distribution of roughhead and roundnose grenadiers in the Northwest Atlantic. NAFO SCR Doc., No. 94, Serial No. N1398, 28 p.

ATKINSON, D. B., D. POWER, and J. MORGAN. MS 1994. Roundnose grenadier (Coryphaenoides rupestris) and roughhead grenadier (Macrourus berglax) in NAFO Subareas 2+3. NAFO SCR Doc., No. 48, Serial No. N2419, $11 \mathrm{p}$.

BERGSTAD, O. A. 1990. Distribution, population structure, growth and reproduction of the roundnose grenadier, $\mathrm{Co}$ ryphaenoides rupestris (Pises: Macrouridae) in the deep waters of the Skagerrak. Mar. Biol., 107(1): 25-40. 
BOWERING, W. R., D. POWER, and M. J. MORGAN. MS 1995. Distribution and abundance of five major groundfish species at the continental slope of Divisions 3KLMN based upon Canadian deepwater surveys in 1991, 1994 and 1995. NAFO SCR Doc., No. 51, Serial No. N2562, 18 p.

CASAS, J. M. MS 1994. Age structure of roughhead grenadier (Macrourus berglax) on Flemish Cap, 1994. NAFO SCR Doc., No. 80, Serial No. N2459, 5 p.

CASAS, J. M., and D. GONZÁLEZ-TRONCOSO. MS 2005. Results from bottom trawl survey on Flemish Cap of July 2004. NAFO SCR Doc., No. 35, Serial No. N5121, 35 p.

DE CARDENAS, E., J. M. CASAS, R. ALPOIM, and H. MURUA. MS 1996. Preliminary results of the European long-line survey in the NAFO Regulatory Area. NAFO SCR Doc., No. 34, Serial No. N2709, 6 p. (+ corrigendum)

D'ONGHIA, G. D., M. BASANISI, and A. TURSI. 2000. Population structure, age and growth of macrourid fish from the upper slope of the Eastern-Central Mediterranean. J. Fish Biol., 56: 1217-1238. doi: 10.1006/jfbi.2000.1243.

ELIASSEN, J. E., and I. B. FALK-PETERSEN. 1985. Reproductive biology of the roughhead grenadier (Macrourus berglax Lacepede) (Pisces, Gadiformes) from the continental slope of northern Norway. Sarsia, 70(1): 59-67.

FOSSEN, I., O. A. JØRGENSEN, and A. C. GUNDERSON. 2003. Roughhead grenadier (Macrourus berglax) in the Waters off East Greenland: Distribution and biology. J. Northw. Atl. Fish. Sci., 31: 285-299.

GEISTDOERFER, P. 1975. Ecological types of food of Macrouridae (Teleosteens Gadiformes) feeding morphology and histology of the digestive systems. The place of Macrouridae in the deep-sea food chain. These $\mathrm{PhD}$. Universite de Paris, Paris, France. Can. Trans. Fish Aquat. Sci., 4570, $278 \mathrm{p}$.

1979. New data on the reproduction of macrourids (Teleostei, Gadiformes). Sarsia, 64: 109-112.

1986. Macrouridae. In: Fishes of the North-eastern Atlantic and Mediterranean 2, 517-1007. P. J. P. Whitehead, M. L. Bauchot, J. C. Hureau, J. Nielsen, and E. Tortosone (eds.). p. 644-676. (Paris:Unesco).

GONZÁLEZ, F., J. L. DEL RÍO, A. VÁZQUEZ, H. MURUA, and E. ROMÁN. MS 2004. Spanish Research Report for 2003. NAFO SCS Doc., No. 9, Serial No. N4963, 24 p.

GONZÁLEZ-TRONCOSO, D., and J. M. CASAS. MS 2005. Calculation of the calibration factors from the comparative experience between the R/V Cornide de Saavedra and the R/V Vizconde de Eza in Flemish Cap in 2003 and 2004. NAFO SCR Doc., No. 29, Serial No. 5115, 8 p.

GONZÁLEZ-TRONCOSO, D., X. PAZ, and F. GONZÁLEZ. MS 2005. Results for the roughhead grenadier from the Spanish surveys conducted in the NAFO Regulatory Area of Divisions 3NO, 1997-2004. NAFO SCR Doc., No. 28, Serial No. N5114, $18 \mathrm{p}$.

HAEDRICH, R. L., and N. R. MERRET. 1988. Summary atlas of deep-living demersal fishes in the North Atlantic Basin. J. Nat. Hist., 22: 1325-1362.

HOUSTON, K. A. MS 1983. Food sources for deep-sea fishes on the Newfoundland continental slope. NAFO SCR Doc., No. 89, Serial No. N755, 19 p.

HUREAU, J. C., P. GEISTDORFER, and M. RANNOU.
1979. The ecology of deep-sea benthic fish. Sarsia, 64(1-2): 103-108.

JØRGENSEN, O. A. 1995. A comparison of deep water trawl and long-line research fishing in the Davis Strait. In: Deep water fisheries of the North Atlantic Oceanic slope. A. G. Hopper (ed.). Kluwer Academic Publishers. Netherlands, NAFO ASI Series, E296: 235-250.

1996. Distribution and biology of grenadiers (Macrouridae) in West Greenland Waters. J. Northw. Atl. Fish. Sci., 18: 7-29.

JØRGENSEN, O. A., and J. BOJE. MS 1992. A comparison of the selectivity in trawl and long-line fishery for Greenland halibut NAFO SCR Doc., No. 53, Serial No. N2244, 5 p.

JUNQUERA, S. MS 1998. A proposal to rename the STACFIS section dealing with grenadiers. NAFO SCR Doc., No. 28, Serial No. N3013, 1 p.

JUNQUERA S., H. MURUA, and K. PATTERSON. MS 2001. Monitoring update of the roughhead grenadier stock assessment in NAFO Subareas 2 and 3. NAFO SCR Doc., No. 75, Serial No. N4454, 16 p.

KATSAROU, E., and G. NAEVDAL. 2001. Population genetic studies of roughhead grenadier, Macrourus berglax L., in the North Atlantic Ocean. Fish. Res., 51: 207-215.

KOELLER, P. A. 2000. Relative importance of abiotic and biotic factors to the management of the Northern shrimp (Pandalus borealis) fishery on the Scotian Shelf. J. Northw. Atl. Fish. Sci., 27: 21-33.

KONSTATINOV, K. G. 1976. Morpho-functional peculiarities of Greenland halibut and grenadiers associated with movements and feeding. Tr. PINRO, Murmansk, 37: 26-34.

LEIM, A. H., and W. B. SCOTT. 1966. Fishes of the Atlantic coast of Canada. Bull. Fish. Res. Board Can., 155, 485 p.

LILLY, G. R., D. G. PARSONS, and D. W. KULKA. 2000. Was the increase in shrimp biomass on the Northeast Newfoundland shelf a consequence of a release in predation pressure from cod. J. Northw. Atl. Fish. Sci., 27: 45-61.

MAGNUSSON, J. V. MS 1978. On the distribution and spawning grounds of the roughhead grenadier (Macrourus berglax) west of Iceland. ICES C.M. Doc., No. G:36, 10 p.

MARSHALL, N. B. 1965. Systematic and biological studies of the Macrourid fishes (Anacanthini-Teleostii). Deep-Sea Res., 12: 299-322.

McCALLUM, B. R., and S. J. WALSH. 1996. Groundfish survey trawls used at the Northwest Atlantic Fisheries Centre, 1971-present. NAFO Sci. Coun. Studies, 29: 93-104.

MERRETT, N. R., and R. L. HAEDRICH. 1997. Deep-sea demersal fish and fisheries. Chapman and Hall, London, U.K.

MURUA, H. 2003. Population structure, growth and reproduction of roughhead grenadier on the Flemish Cap and Flemish Pass. J. Fish Biol., 63: 356-373.

MURUA, H., and L. MOTOS. 2000. Reproductive biology of roughhead grenadier (Macrourus berglax Lacepède, 1801) (Pisces, Macrouridae), in Northwest Atlantic waters. SARSIA Nord. J. Mar. Biol., 85: 393-402.

MURUA, H., and F. GONZÁLEZ. MS 2004. A review on roughhead grenadier (Macrourus berglax) biology and population structure on Flemish Cap (NAFO Division 3M) 1991-2003 based upon EU Flemish Cap bottom survey data. NAFO 
SCR Doc., No. 14, Serial No. N4961, 19 p.

MURUA, H., F. GONZÁLEZ and J. M. CASAS. MS 2005. A review on roughhead grenadier (Macrourus berglax) biology and population structure on Flemish Cap (NAFO Division 3M) 1991-2000 based upon EU Flemish Cap bottom survey data. NAFO SCR Doc., No. 36, Serial No. N5122, $18 \mathrm{p}$.

MURUA, H., and E. DE CÁRDENAS. 2005. Depth distribution of deep water species in Flemish Pass. J. Northw. Atl. Fish. Sci., 37: 1-12.

NAFO. 2005. Northwest Atlantic Fisheries Organization. Scientific Council Reports, 2005.

PARSONS, L. S. MS 1976. Distribution and relative abundance of roundnose, roughhead and common grenadiers in the Northwest Atlantic. ICNAF Ser. Pap., 1: 73-78.

PODRAZHANSKAYA, S. G. 1972. Feeding and food interrelations of different commercial fishes of Northwest Atlantic. Abundance and mode of life of commercial fishes of Northwest Atlantic. Sbornik nauchnych trudov. Tr. PINRO, Murmansk, p. 112-123.

POWER, D., and D. MADDOCK PARSONS. MS 1998. An assessment of roundnose grenadier (Coryphaenoides rupestris) in NAFO Subareas $2+3$ and catch information on roughhead grenadier (Macrourus berglax). NAFO SCR Doc., No. 57, Serial No. N3049, 11 p.

RODRÍGUEZ-MARÍN, E., M. RUIZ, and A. SARASUA. 2002. Validation of roughhead grenadier (Macrourus berglax) otolith reading. J. Appl. Ichthyology, 18: 70-80.

ROMÁN, E., C. GONZÁLEZ, and E. CEBALLOS. 2006. Food and feeding of most abundant fish species in Flemish Cap.
J. Northw. Atl. Fish. Sci., 37: (this volume).

SAVVATIMSKY, P. I. 1969. Grenadier of the North Atlantic. PINRO, Murmansk, $72 \mathrm{p}$.

MS 1983. Distribution, biological characteristics and percentage of roughhead grenadier in the catches form the Grand Newfoundland area in May-July 1982. NAFO SCR Doc., No. 45, Serial No. N702, 21 p.

1984. Biological aspects of roughhead grenadier (Macrourus berglax L.) from longline catches in the Eastern Grand Bank Area, 1982. NAFO Sci. Coun. Studies, 7: 45-51.

1989. Investigations of roughhead grenadier (Macrourus berglax L.) in the Northwest Atlantic, 1967-83. NAFO Sci. Coun. Studies, 13: 59-75.

1994. Age structure of of roughhead grenadier (Macrourus berglax L.) in the Northwest Atlantic, 1985. NAFO Sci. Coun. Studies, 20: 53-64.

SNELGROVE, P. V. R., and R. L. HAEDRICH. 1985. Structure of the deep demersal fish-fauna off Newfoundland. Mar. Ecol. Prog. Ser., 27: 99-107.

YANULOV K. P. 1962. On the reproduction of the roughhead grenadier (Macrourus berglax Lacépède). Zool. Zh., 8: $1259-1262$.

VARGAS, J., R. ALPOIM, E. SANTOS and A. M. ÁVILA DE MELO. MS 2004. Portuguese Research Report for 2003. NAFO SCS Doc., No. 5, Serial No. N4949, 50 p.

VASKOV, A. A., K.V. GORCHINSKY, T. M. IGASHOV and S. P. MELNIKOV. MS 2004. PART II - Research carried out by PINRO in NAFO Subareas 1, 2 and 3. NAFO SCS Doc., No 3, Serial No. N4945, 24 p. 
